\title{
Hydrogeophysical methods and hydrogeological models: basis for groundwater sustainable management in Valle Alto (Bolivia)
}

\author{
Andres Gonzales Amaya ${ }^{1,2}$ ( Jhylmar Ortiz ${ }^{3} \cdot$ Alfredo Durán $^{3} \cdot$ Mauricio Villazon $^{2}$
}

Received: 16 March 2018 / Accepted: 22 October 2018 / Published online: 26 October 2018

(c) The Author(s) 2018

\begin{abstract}
In Bolivia climate change and anthropogenic activities such as extensive agriculture, industries and urbanization have increased the groundwater demand and extraction, which is leading to severe stress on groundwater resources in several regions of Bolivia. This research aims to present an overview of different geophysical surveys performed in Valle Alto (central Bolivia), in particular in the Punata and Toco alluvial fans. The application of geophysics can have an implication in broadening the knowledge about local aquifers, which later might assist in proposing sustainable groundwater exploitation and protection plans. The geophysical results revealed two similar aquifer systems contained in unconsolidated sediments. A refinement of the hydrogeological conceptual models in terms of layering, lateral variation and thicknesses was performed in both areas. Moreover, geophysical surveys revealed geological features such as faults and saline regions which have not been reported previously in other studies. Such information is aimed to be the basis for further debates on groundwater protection, management, planning, and decision-making between local water user organizations and municipalities.
\end{abstract}

Keywords Groundwater · Geophysical methods · Conceptual model · Bolivia

\section{Introduction}

Access to water has always played an important role in human settlements and its daily activities. However, in developing countries, such as Bolivia, the water accessibility generally is not equally distributed in time and space due to climate aspects, and in a less extent due to weak economy aspects (Lobina 2000; Saldías et al. 2012). In Bolivia the high prices for water access/services in addition to frequent droughts are increasing the conflicts between farmers and private companies (Wutich and Ragsdale 2008). In 2001 the so called water war took place in the city of Cochabamba, which in that moment was the third largest city of Bolivia. This region is characterized for being a semiarid area with constant water shortages. The conflict was triggered because

Andres Gonzales Amaya

andres.gonzales@gmail.com

1 Engineering Geology, Lund University, Box 118, 22100 Lund, Sweden

2 Laboratorio de Hidráulica, Universidad Mayor de San Simón, Av. Petrolera km 4.2, Cochabamba, Bolivia

3 Centro AGUA, Universidad Mayor de San Simón, Av. Petrolera km 5, Cochabamba, Bolivia the water and sanitation systems were privatized. The privatization increased the prices of basic services with $200 \%$ or more (Lobina 2000), and allowed the private companies to manage and control all kind of water sources such as lakes, springs and wells. Furthermore, the effects of climate change and water shortages in many arid and semiarid zones are threatening the already stressed water sources. For instance, during the years 2015-2016, the second largest lake in Bolivia, Poopo lake, dried up completely due to a large number of man-made outlets along Desaguadero river, which is the main tributary of Poopo lake (Allen 2016; Satgé et al. 2017). Moreover, in the same years, the main cities of Bolivia suffered from water supply shortages affecting more than 3 million inhabitants. As a result, in several places of Bolivia there is a deficit in water supply, such as in the Valle Alto region of Cochabamba (refer to Fig. 1), which relies mainly on the groundwater supply and is the case study of this article.

However, in Bolivia (over)exploitation of groundwater occurs under the absence of detailed knowledge and understanding about the dynamics of groundwater, and the main hydrogeological processes (Duran 2018). Since groundwater becomes a valuable common good and often is the cornerstone of several ecosystems, it is necessary to implement an 


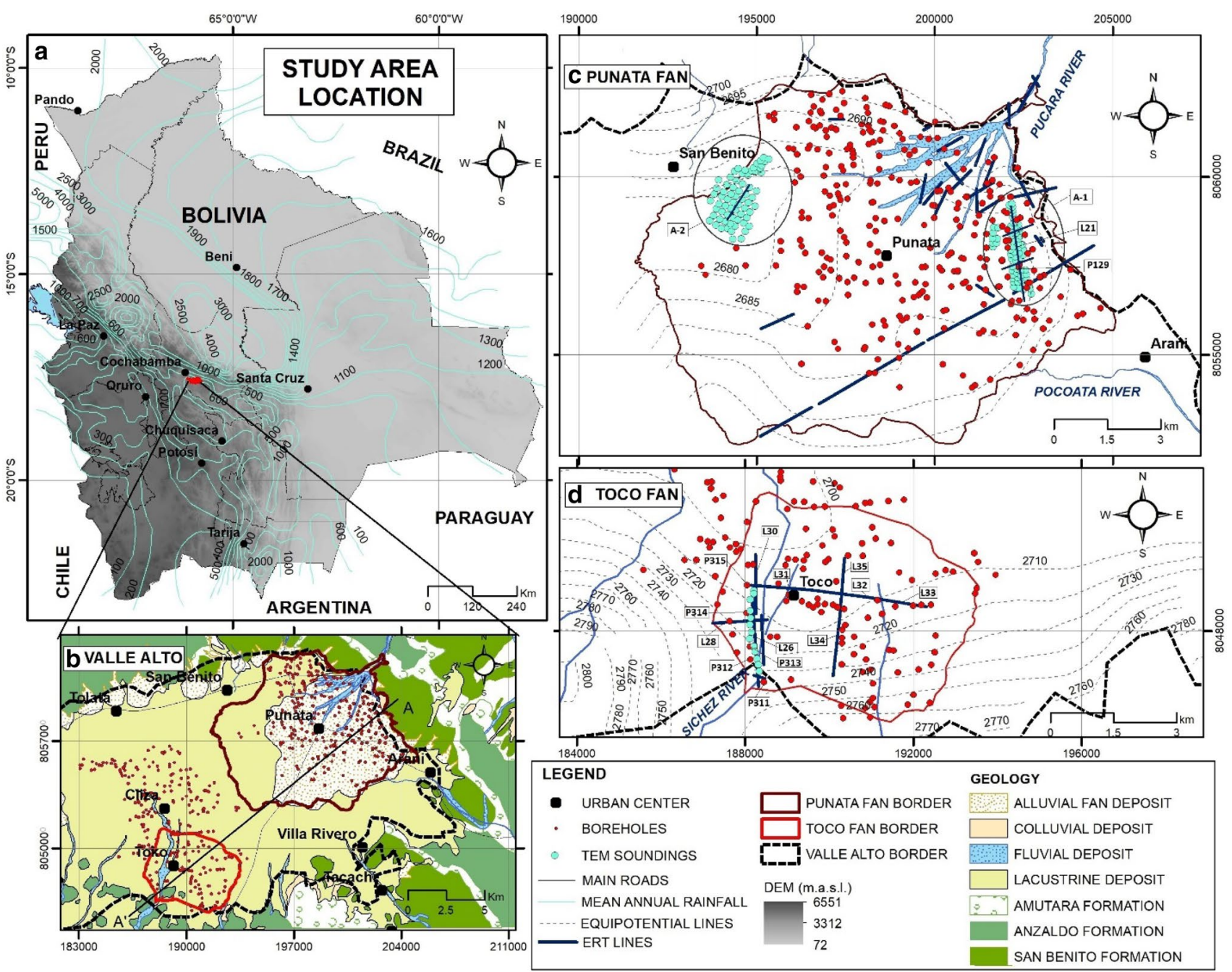

Fig. 1 a Study area location and Bolivia distribution of mean annual rainfall and ground surface elevation. b Study areas location within Valle Alto, geological description, and drilled wells. c, d Performed geophysical surveys in Punata and Toco alluvial fans, respectively

effective policy of groundwater management and protection based on an adequate understanding of the hydrogeological properties and processes. To plan strategies for sustainable groundwater management it is necessary to retrieve basic information such as the aquifer geometry, where geophysical surveys can be a key method.

Successful national groundwater management plans were proposed after extensive geophysical investigation, such as in New Zeeland, Denmark and Australia (Daughney and Reeves 2005; Grey et al. 2013; Habermehl 2006; Klee 2013; Thomsen et al. 2004; UN-Water 2013). For instance, Denmark succeeded in the elaboration of accurate maps of their aquifers with respect to their location, extension, distribution and interconnection. These maps assist in identifying weak points in groundwater protection and exploitation. Groundwater mapping based only on drilling information might lead to many uncertainties in the models due to the frequent low borehole density. Therefore, one of the most important means used by Denmark for mapping their aquifers was a combination of a small number of boreholes investigations with intensive and large-scale geophysical methods, in particular airborne electromagnetic (i.e., SkyTEM) surveys (Klee 2013; Sørensen and Auken 2004).

The International Hydrological Programme (IHP) of the United Nations Educational Scientific and Cultural Organization (UNESCO) has been funding and promoting projects where the enhance of water resources management and governance are the priorities. These types of projects showed that the involvement of different organizations, institutions and local actors is important for improving the sustainable management of water resources (UN-Water 2013; UNESCO 2015). Hence, in the Valle Alto region, the University Mayor de San Simón (UMSS) forms part of the project Integrated Water Resources Management (IWRM) cofounded by the 
Swedish International Development Agency (SIDA), and of the project Sustainable Groundwater Strategies (SGS) cofounded by the Swiss Cooperation in Bolivia (SWB). Both projects have performed several geophysical surveys to retrieve information about the aquifers geometry in the Punata and Toco alluvial fans, both located in the eastern and southern part of Valle Alto, respectively (Fig. 1). The collected geophysical information can be used to support the development and/or refinement of hydrogeological conceptual models of the aquifers, which later can be used as a basis for a discussion with the local actors (e.g., municipalities and water user organizations). The discussions must deal with the planning of strategies and actions to be incorporated to design sustainable protection plans of groundwater at local and regional levels. The interaction between applied research and local actors at decision-making levels is taking place through the on-going process of building-up a methodology for the Plan of Aquifer Management (PAM) of Bolivia, which is initiated by the same team at UMSS which is researching at Valle Alto. Hence, there is a factual chance to integrate hydrogeophysical studies into the management plans of the municipalities at Valle Alto. Therefore, this paper aims to present an overview of the different geophysical methods and surveys carried out in the Valle Alto region. The resultant conceptual models will be used for interactive debates with local actors to develop sustainable groundwater management plans.

\section{Methodology}

\section{Study areas}

The Valle Alto basin (Fig. 1b) is the second most densely populated region in central Bolivia with an extension of approximately $500 \mathrm{~km}^{2}$ and 150,000 inhabitants (INE 2012). This basin has large areas of fertile soils, which makes Valle Alto one of the most important areas of Bolivia in terms of agriculture production. For instance, in Punata and Toco regions about $57 \%$ of the local population works in the agriculture and related activities (Saldías et al. 2013). However, Valle Alto is a semiarid region, where access to surface water is very limited. The annual rainfall is in average is less than $500 \mathrm{~mm}$, and the annual potential evapotranspiration can be as high as $1900 \mathrm{~mm}$. Therefore, to cover the surface water deficit, the local population makes an extensive use of groundwater. There are about 2000 wells drilled in Valle Alto and the production rate varies from 1 to $25 \mathrm{l} / \mathrm{s}$. The Punata and Toco alluvial fans are considered the most important areas in terms of groundwater production due to its good water quality and high yields, therefore, they are used as case studies.
The Valle Alto basin is surrounded by a mountainous massif formed of Ordovician and Silurian rocks, where the peaks can reach 4000 meters above sea level (m.a.s.l.). The San Benito, Anzaldo and Amutara formations are most representative rocks in the study area. These rocks, typically sandstone, also formed the study area basement, and commonly are considered as impermeable. However, a secondary porosity might be originated after tectonic movements, and is manifested as small springs in the northern part of the basin. During the early Pliocene the tectonic activity in the central Andes has caused the creation of several graben valleys located in the sub-Andean region (e.g., Valle Alto), and consequently enclosed lakes were created. The weather in that period was predominately dry, and saline material with high clay content was deposited. With time these graben valleys were filled with Quaternary deposits (BRGM-SEURECA 1990; GEOBOL 1983; May et al. 2011; UNDP-GEOBOL 1978).

The unconsolidated Quaternary deposits in Valle Alto are mainly formed of lacustrine, fluvial, colluvial and alluvial fan sediments. These deposits form terraces on riverbanks, beds and alluvial fans at the mouths of creeks and rivers. The grain size of the Quaternary deposits decreases towards the central part of the basin, where the lacustrine sediments (i.e., mostly clay) are dominant. Collected topsoil samples showed that it is very likely to find a semipermeable layer composed of clay and sand. The thickness of this topsoil layer vary from few centimeters up to $2 \mathrm{~m}$ in the apex and middle of the fan, respectively. The Quaternary deposits with high primary effective porosity are important in terms of groundwater storage. The main aquifers are located within the alluvial fans, and generally are unconfined in the upper parts and becomes semiconfined, by the semipermeable topsoil layer, to confined towards the center of the basin. The water table (Fig. 1c, d) can vary from approximately 2770 to 2680 m.a.s.l. in the Punata and Toco regions.

\section{Geophysical surveys}

There are several geophysical methods that can be used for hydrogeological characterization, however, electrical and electromagnetic methods are particularly useful since there are often strong correlations between the measured resistivity and the subsurface lithology. There are many scientific researches which have used these methods worldwide (Ahzegbobor 2014; Danielsen et al. 2003; Giocoli et al. 2008; Gonzales Amaya et al. 2016; Guérin et al. 2001; Keys 2017; Slater 2007; Weller et al. 2013; Yihdego and Nzikou 2018).This research has used the following geophysical methods: electrical resistivity tomography (ERT), time domain induced polarization (TDIP), and transient electromagnetics (TEM). 
ERT data were acquired using an ABEM Terrameter LS equipment. The surveys were carried out by placing steel electrodes in the ground and then performing simultaneous automated measurements. The measurements are acquired by different combinations of four electrodes, i.e., two current electrodes and two potential electrodes, and involves the measuring of the potential difference. The field measurements are in terms of apparent resistivity, which can be interpreted as the electrical resistivity of a homogeneous equivalent medium. The values of apparent resistivity were inverted for a two-dimensional image with RES2DINV using the L1-norm (Loke 2010; Loke and Dahlin 2002; Loke et al. 2003), for measurements conducted in both areas. For more detail about the ERT surveys refer to Gonzales Amaya et al. (2016).

TEM surveys were performed with an ABEM WalkTEM. The layout set up consisted in placing a transmitter loop of $50 \times 50 \mathrm{~m}$ for all the soundings. Two receiver loops were used: an inner one of $0.5 \times 0.5 \mathrm{~m}(\mathrm{RC}-5)$, and an outer one of $10 \times 10 \mathrm{~m}$ (RC-200). Both receiver antennas measure soundings with high moments (HM) and low moments (LM). The HM allows to retrieve information from deeper levels with poor resolution near to the surface, while the LM allows to retrieve information with good resolution close to the surface, but with a poor depth of penetration. The acquired measurements were inverted using SPIA software. The inversions were made by selecting the LM from RC-5 and the HM from RC-200. The RC-5 has a better resolution near the surface, while RC-200 reaches deeper levels. The final 1-D inverted models were exported to Workbench where 2-D profiles were created. For more detail about the TEM surveys refer to Gonzales Amaya et al. (2018b).

When time allowed, data acquisition was done with combined measurement of resistivity and induced polarization. The TDIP surveys are carried out by transmitting current into the ground while potential difference is measured to determinate the resistivity. After the current is turned off, the potential decay in the ground is measured again in one or several time windows. A common parameter used to quantify the TDIP measurements is the chargeability, which is defined as the ratio of the secondary potential over the primary potential of the transmitted current (Magnusson et al. 2010; Olsson et al. 2015; Power et al. 2018; Revil et al. 2015; Slater and Lesmes 2002; Sumner 2012). Dividing the chargeability with the measured resistivity yields the normalized chargeability, which can highlight areas with high surface conductance properties (Magnusson et al. 2010; Slater and Lesmes 2002). The timing setup used for these surveys applied a current-on of $1 \mathrm{~s}$, with an acquisition delay time of $0.4 \mathrm{~s}$ and an acquisition time of $0.6 \mathrm{~s}$. A total of nine time windows were measured, where each window time is a multiple period time of $20 \mathrm{~ms}$ to suppress any power line noise.
Together, in Punata and Toco areas, about 140 TEM soundings and $43 \mathrm{~km}$ of ERT lines were performed. When conditions allowed, the roll-along technique was applied for getting continuous profiles. The selection of ERT, TDIP, and TEM locations were planned according to the availability of areas free of obstacles and noise such as houses, fences, crops, power lines, and paved roads. After the processing of the geophysical surveys, the results are interpreted with lithology reports from boreholes close to or within the surveys. The interpretation of the electrical resistivity values makes it possible to evaluate the lateral and vertical variation of different geological units, which later are used for proposing and/or refining hydrogeological conceptual models. The conceptual models are useful resources for depicting the extension, distribution and layering of the aquifer system, therefore, these models can be used for further discussion between the technicians, decision-makers, and local actors.

\section{Results and discussions}

\section{The Punata alluvial fan}

Figure 2 shows the typical results found in the Punata alluvial. High resistivity values were found in the top layers ranging from 100 to $500 \Omega \mathrm{m}$, and the profiles showed a trend of decreasing resistivity values with depth. Generally, the values in the bottom of the profiles are in the order of $10 \Omega \mathrm{m}$, however, in some regions the resistivity values can be less than $5 \Omega \mathrm{m}$ (Fig. 2a). Lithological information from wells located close or within the geophysical surveys were used for the interpretation process. Figures $2 \mathrm{a}$ and $4 \mathrm{a}$ include wells located in the resistivity profiles. For both case studies, the main material of each layer is shown by their initial letter: i.e., B, G, S, and C stands for boulder, gravel, sand and clay, respectively; For example, a layer with letters GS means that the material in that layer is mainly composed of gravel and sand. Mostly all the lithology logs describe a grain gradation from coarse at the top to fine at the bottom.

Figure 2a displays an example of how the interpretation of the resistivity profiles was done. High values of resistivity in the top layers are related to coarse materials such as boulder, gravel and sand. Coarser material is likely to have been deposited by flash floods from Pucara river and other smaller streams. On the contrary, low values on the bottom of the resistivity profiles were related to fine material such as clay and silt, and this might be explained by the deposition of fine sediments from former paleolakes during the Pliocene (GEOBOL 1983; UNDP-GEOBOL 1978).

Figure $2 \mathrm{~b}$ displays the normalized chargeability profile. Conversely, high values were located at the bottom of profiles, while lower values were found on the top layers. Normalized chargeability can be highly dependent on clay 
Fig. 2 Example of resistivity and normalized chargeability interpretation for line 21 (refer to Fig. 1c for location). a Electrical resistivity profile. b Normalized chargeability profile. $\mathbf{c}$ Hydrogeological interpretation

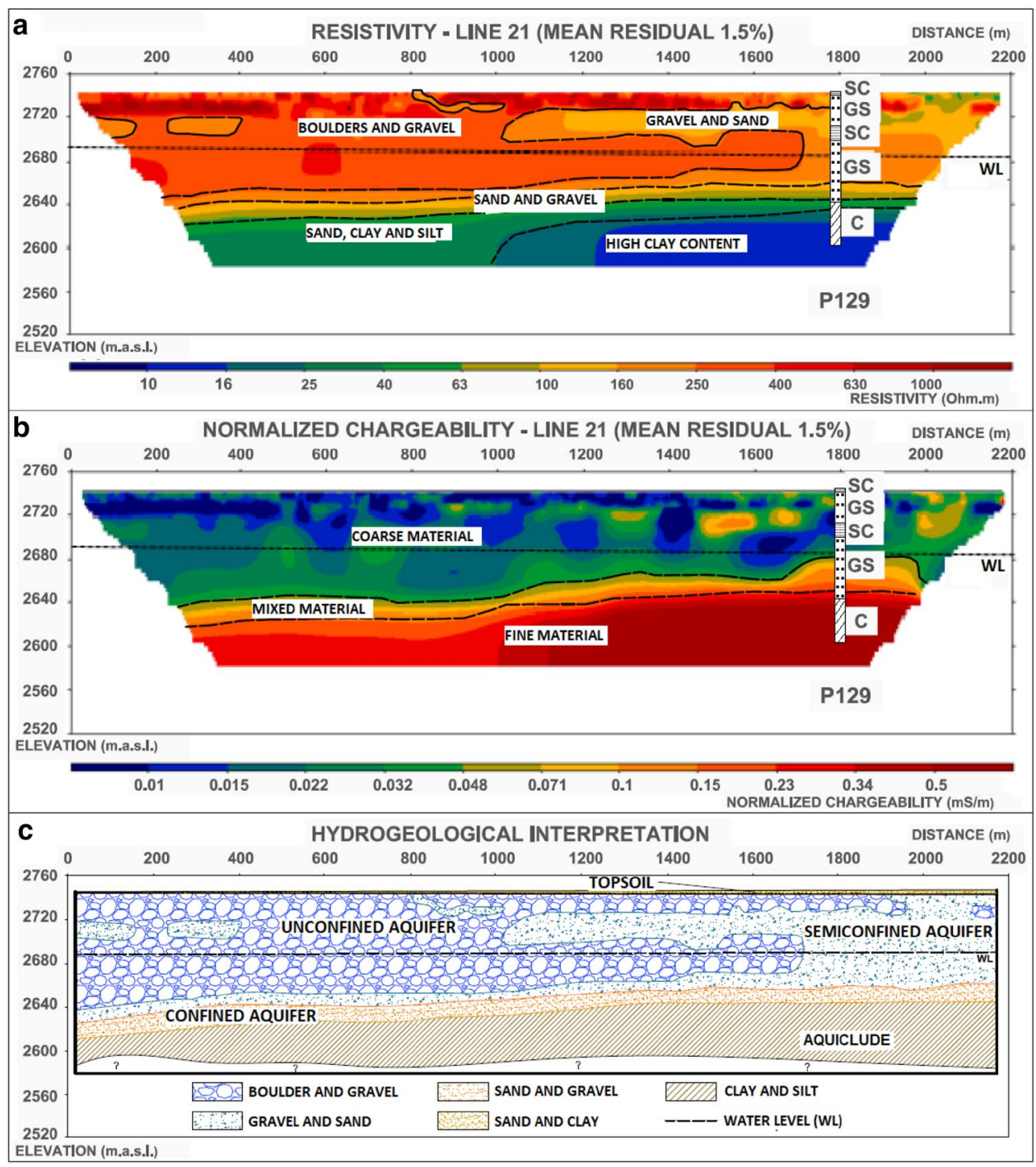

mineralogy and clay content (Revil et al. 2015; Revil and Florsch 2010; Weller et al. 2013). Moreover, the normalized chargeability shows low values when uniform particle sizes of sand and gravel are present, whereas for fine grains the values are greater, similar results were found by Koch et al. (2012). Therefore, in the study area values of normalized chargeability assisted during the interpretation process in clarifying the differences between areas with high clay content (high values of normalized chargeability at the bottom of profiles) and coarse material (low values of normalized chargeability at the top of profiles). Figure $2 \mathrm{c}$ displays the hydrogeological interpretation of the example profile. Due to the ERT layout restrictions the first meters of the topsoil were not solved accurately. Collected topsoil samples, composed mainly of clay and sand, indicated that the thickness of this layer increases toward the middle and distal part of the fan, thus it is possible to differentiate an unconfined and a semiconfined aquifer in the upper and middle part of fan, respectively. The unconfined aquifer is mainly composed of coarse material, which has a good primary porosity, and thus, groundwater storage capacity. The semiconfined unit is formed by gravel in a matrix of sand and clay, and generally is located from the middle to the distal part of the fan. This aquifer might be semiconfined by thin semipermeable layers of clay and sand. The clay content increases with the depth, therefore, the bottom part of the aquifer is considered confined by the cap of approximately $100 \mathrm{~m}$ of sediments. The confined aquifer is composed of sand, clay and silt, and generally wells at that depth have very low yield. Finally, the aquiclude is the confining bottom of the aquifer system, composed of clay and silt.

However, due to the ERT layout restrictions, the maximum depth of investigation (DOI) was limited to approximately $150 \mathrm{~m}$. The DOI did neither allow to determine the thickness of bottom layer with a high clay content, nor to detect the depth to the bedrock. Therefore, to achieve a better knowledge about deeper layers the TEM method was used. The DOI for TEM surveys varied from 170 to $210 \mathrm{~m}$, and 
none of them could cross the high clay content bottom layer. However, TEM surveys yielded important complementary information. For example, local reports indicated poor groundwater quality (i.e., high salts concentration) in some wells, therefore, TEM surveys allowed to detect a saline water zone which is overlaying the high clay content bottom layer (Fig. 3a). The low values of resistivity (e.g., $0.5-1 \Omega \mathrm{m}$ in $\mathrm{A} 1$, and values as lower as $0.1 \Omega \mathrm{m}$ in $\mathrm{A} 2$, refer to Fig. 1c for locations) might be associated as a result of the mixing of fresh water with residual saline pore water in the high clay content bottom layer, and/or ion exchange within this layer. Furthermore, the resistivity results in A1 displayed a zone whit high resistivity in the northern bottom part (refer to the northern part of Fig. 3a). This region is conversely to what was expected: the bottom layer is dominated by clay, and therefore, low values of resistivity would be expected. Therefore, this zone with high resistivity values might be explained by a fault which is protruding through the high clay content bottom layer. If this high resistivity zone is bedrock protruding and it is fractured, it might be interesting from a hydrogeological point of view, since groundwater might be stored within the fractures. Figure $3 b$, displays how TEM results might contribute in enhancing the hydrogeological conceptual models within areas with large grain size heterogeneity such as the Punata alluvial fan.

\section{The Toco alluvial fan}

Figure 4a displays an example of how resistivity values varied in the Toco fan. In this figure the resistivity profile is not continuous due to the fact that a paved road was located at approximately at $2200 \mathrm{~m}$ of distance. Therefore, it was not possible to install the electrodes in the road and consequently no readings were obtained below the paved road. Resistivity values in the top layers ranged in average from 50 to $400 \Omega \mathrm{m}$. The thickness of the top layer varies from $10 \mathrm{~m}$ within the upper part of the fan to $60 \mathrm{~m}$ in the distal part of the fan. The resistivity values tend to decrease with depth, however, in the zones close to the mountain massif (southern boundary of Valle Alto) the resistivity values ranged from 100 to $300 \Omega \mathrm{m}$. On the other hand, in the middle and distal part of the fan, the resistivity values of the bottom layers are between 10 and $25 \Omega \mathrm{m}$. Figure $4 \mathrm{~b}$ shows how ERT surveys were interpreted in the Toco fan. Boreholes close or within ERT surveys were used for interpreting the resistivity distribution, as well as for the hydrogeological interpretation. In general, the high resistivity values in the top layers are associated to an unconfined aquifer formed of coarse materials such as boulder and gravel. Towards the distal part of the Toco fan a semiconfined aquifer is located beneath the unconfined aquifer. This semiconfined aquifer is formed of finer sediments such as sand and it is surrounded by semipermeable layers of clay. The aquifer system is delimited in the bottom by an aquitard formed of clay. Saline water might be stored in the aquitard pores and might have the same origin as in the Punata region. The high resistivity values on the southern bottom layer are associated to the Ordovician sandstone rocks, which form the basement of the tectonic graben of Valle Alto.

Figure 5 depicts the spatial distribution of the ERT surveys in the Toco fan. Surveys located parallel and perpendicular to the Sichez river (i.e., L26 and L30, and L28 and L31, respectively) showed higher resistivity values in the top layers. These high resistivity values are due to the fact that mountain rivers can transport coarse material, which later is deposited after the river energy decreases. A similar pattern can be observed in the encircled area in L33, where the Tagapi and Chualoma streams cross. These streams are considerable smaller than Sichez river, therefore, they can transport less coarse material, and the thickness of the top layer is thinner than in the Sichez river.

Moreover, in alluvial fans it is typical that the river course changes with time, and this process can be seen in L31 (Fig. 5). The high resistivity lobes in L31 represent the

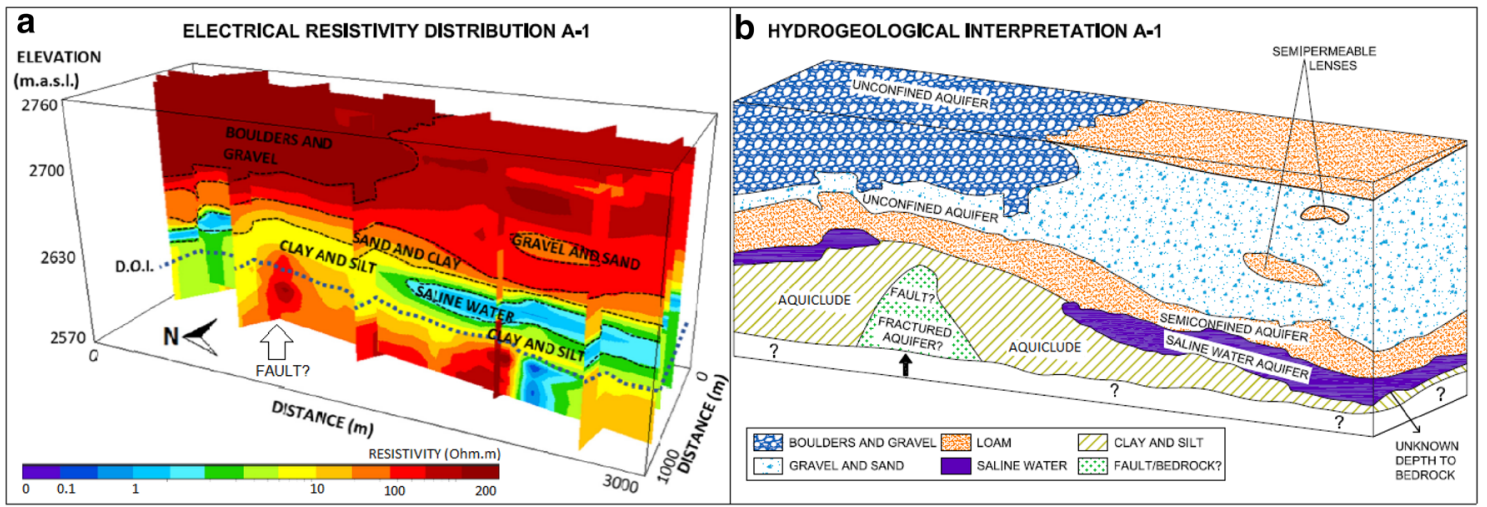

Fig. 3 Example of TEM surveys results. a 3D visualization of the resistivity distribution in A1. b Interpretation in the region of A1 (refer to Fig. 1c for location). Modified from Gonzales Amaya et al. (2018a) 


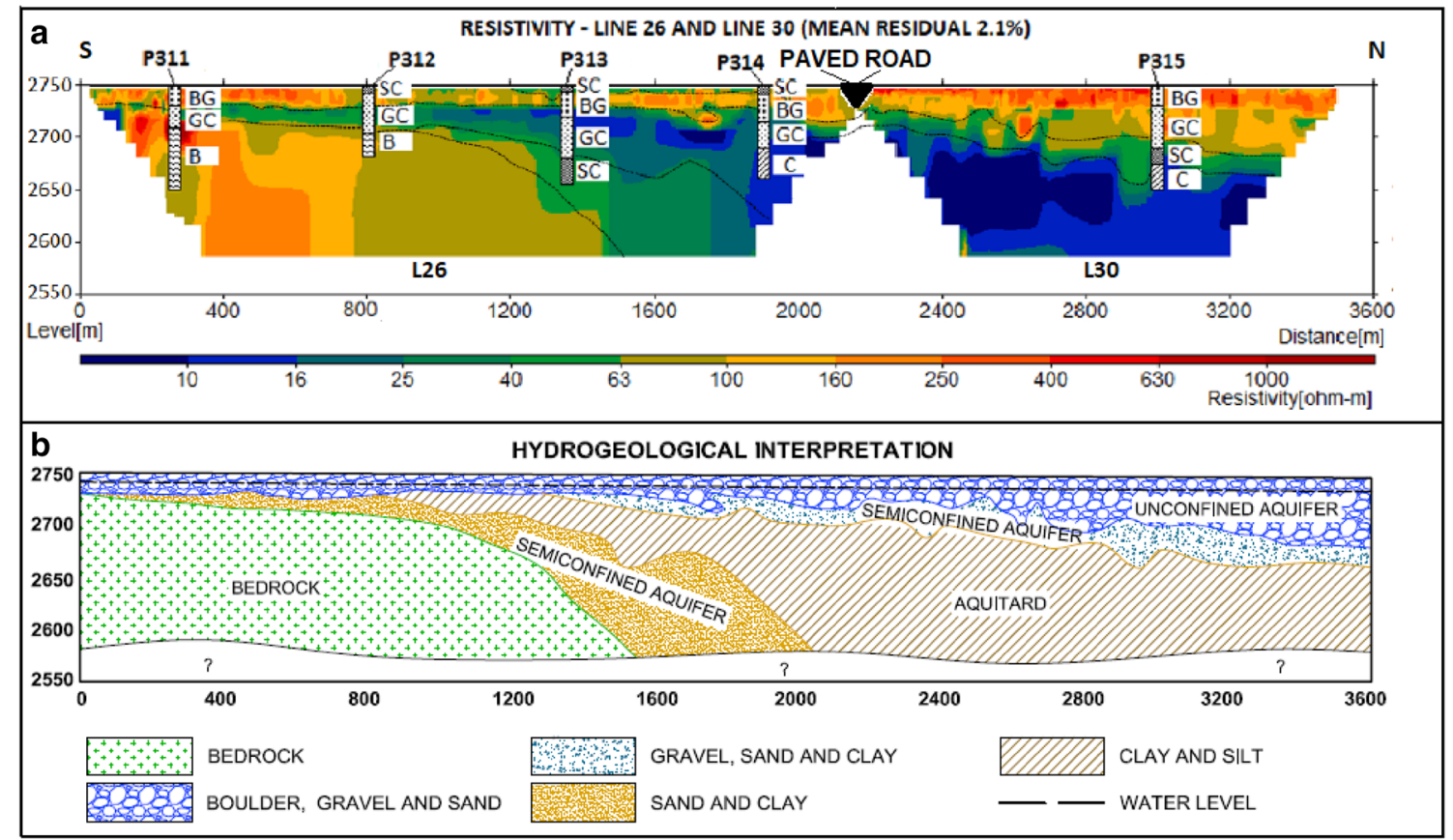

Fig. 4 a Electrical resistivity tomography of line 26 and 30 (refer to Fig. 1d for location). b Hydrogeological interpretation of the resistivity values in the Toco alluvial fan. The meaning of letters B, G, S, C are described in "The Punata alluvial fan"

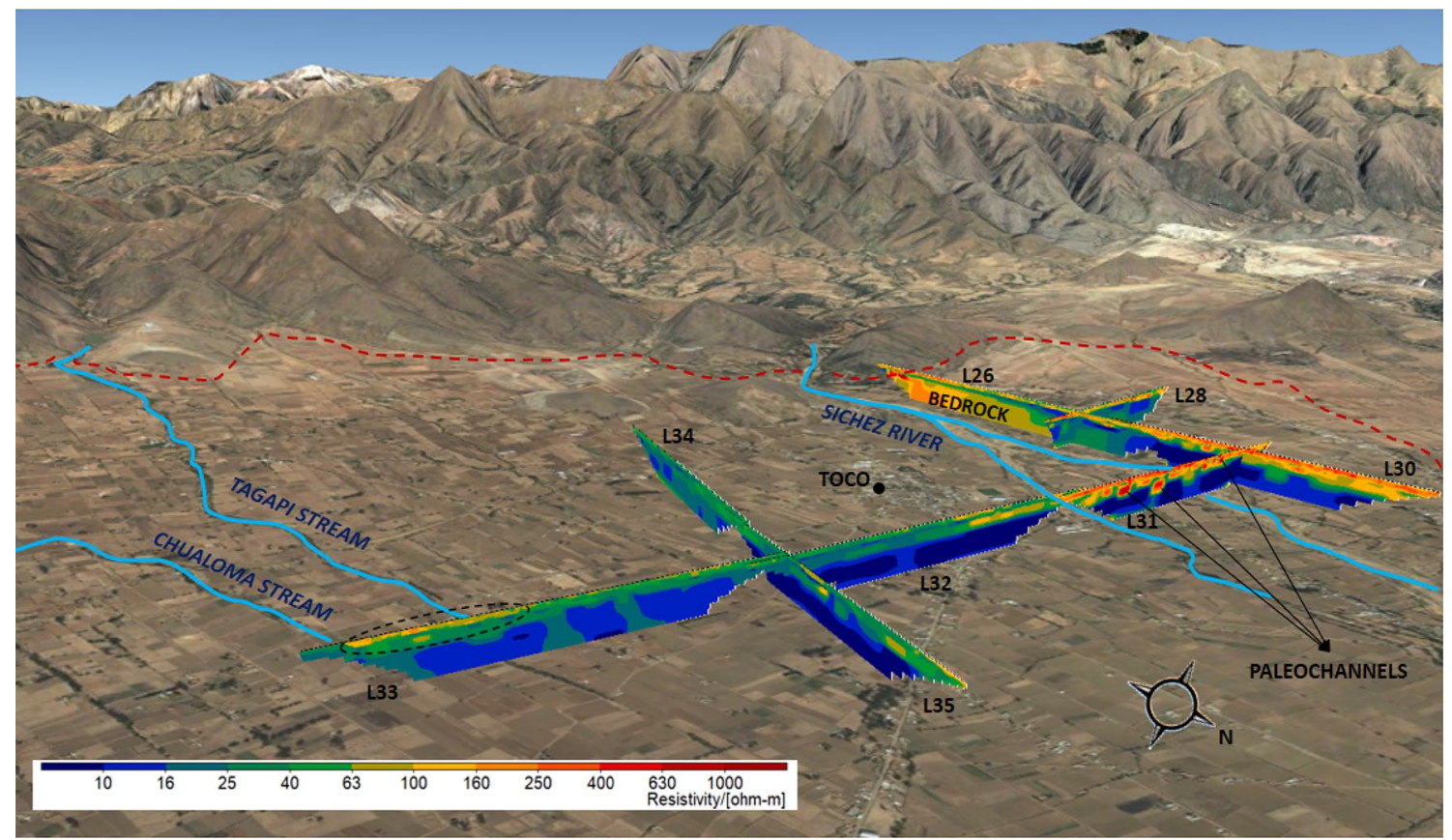

Fig. 5 Spatial distribution of the electrical resistivity tomography surveys in the Toco alluvial fan, and location of the main streams and river in the region

paleochannels of Sichez River, where coarse material was deposited and forms unconfined to semiconfined units, and are the major pathways for groundwater flow. Finally, L26 showed that the bedrock has a softer dipping angle than in the Punata fan (refer to Fig. 6b), which also coincides with the less steep mountains found in the Toco fan apex. ERT 


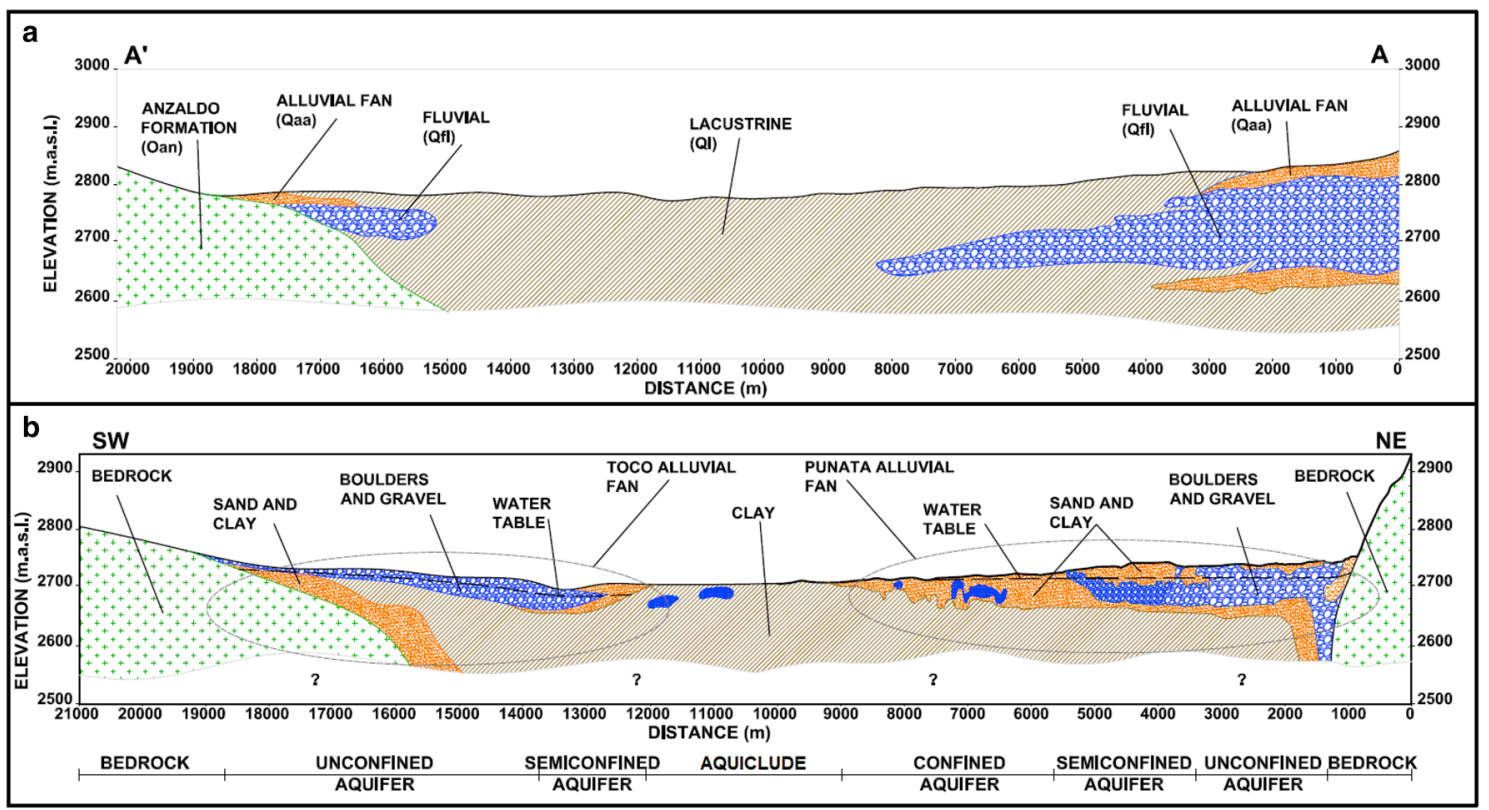

Fig. 6 a Cross section of the hydrogeological conceptual model from 1979. b Refined hydrogeological conceptual model and aquifer system in the direction of $\mathrm{A}-\mathrm{A}^{\prime}$ (refer to Fig. 1b)

profiles which are not close to river or stream courses have in general lower resistivity values, which is explained by the dominance of lacustrine deposition (i.e., sandy clay, clay, and silt deposits) rather than fluvial deposition. Hence, it is expected that these areas are of less importance for groundwater exploration.

\section{General discussion}

The use of geophysical methods was very useful for mapping the aquifer geometry in both study areas. In general, the resistivity values acquired from ERT and TEM methods showed a good agreement. The studies of Gonzales Amaya et al. (2016, 2018b) assessed the variation of the resistivity values from ERT, TEM, and borehole logging. Evidently there are some small differences of resolution detail among the methods; however, all of them followed the same trend. The TEM method, besides of reaching deeper levels, was especially useful for detecting a zone close to the bottom of the aquifer system with very low resistivity values at depths between 110 and $140 \mathrm{~m}$ below surface (2640 and 2610 m.a.s.l.), which was interpreted as a saline zone. Hence the use of geophysical methods such as ERT and TEM are of great value for the characterization and mapping of local aquifers in Valle Alto.

As the interpretation of geophysical results showed a good agreement with the lithology logs, it was expected that a long ERT profile which crosses longitudinally the Punata fan, and ERT surveys in the Toco alluvial fan might provide a better understanding of the aquifer system. The current hydrogeological conceptual model (Fig. 6a, and location is displayed in Fig. 1b) is from 1978 (UNDPGEOBOL 1978), and was elaborated using few scattered lithology logs. Therefore, the geophysical surveys performed in the Punata fan, which cross from the head of the fan towards the distal part, and the ERT surveys in the Toco fan provided enough information for refining the model from 1978. The interpretation of the geophysical results provided more detailed information about the aquifer system in terms of layering, extension, and thicknesses (Fig. 6b). Consequently, it was proven that geophysical surveys can assist in proposing new, or refining, hydrogeological conceptual models in similar environments such as the Punata and Toco alluvial fans.

Geophysical results are improving the information about the layering, layer thicknesses, location of faults, and water of different quality types. Also the interpretation of geophysical results is used for refining the hydrogeological conceptual models. The models in the Punata and Toco alluvial fans, have top layers formed of coarse material, which are the most important aquifer units in terms of groundwater production. These aquifers are located within the alluvial fan bodies, while zones close to the middle part of Valle Alto are of less interest due to the high clay content which reduces the groundwater yield and quality. There are large areas close to the bottom of the aquifer systems, which probably are dominated by saline water. Many well owners have reported bad groundwater quality due to high concentrations of salts, and the reason is due to the fact that the bottom of these wells are close or in contact with these saline layers. 
Therefore, the delimitation of these areas are important when planning to drill new wells.

A conceptual model forms a first approach for understanding the hydrogeological characteristics and processes within the study areas. Therefore, a well-founded conceptual model can be used as a tool for planning a sustainable groundwater management, and for delimiting the most vulnerable areas. The elaboration of these conceptual models constitutes one of the main foreseen instruments by the Bolivian government to implement sustainable management and protection plans of aquifers. Hence the Environmental and Water Ministry of Bolivia (EWMB) has started the design and implementation of the PAM, which aims to generate awareness among all the social actors about the importance of groundwater as a key driver for socioeconomic development. Furthermore, the PAM aims to generate a clear understanding about the role of groundwater in the water balance of ecosystems, and the importance for the welfare of living beings.

Consequently, a team of researchers from UMSS is currently working with the design of the PAM guidelines, which aims to be based on a solid conceptual knowledge of groundwater dynamics, properties, and hydrogeological processes. It is intended to use the Toco fan, and/or the Punata alluvial fan, as an example for the implementation of the methodology of the proposed PAM guidelines. Since both areas, the Punata an Toco fans, have large information about their local aquifers, and there is predisposition from the municipalities and water user organizations, it is intended to use all the information generated from this paper for the developing of the PAM guidelines.

Refining and proposing hydrogeological conceptual models is a task that demands the application of different expertise and disciplines. Despite the fact that it is possible to apply different techniques in alluvial fans for achieving this task, the challenge was to seek appropriate approaches and tools that can be used in the Bolivian context. This type of context means that there is often a lack of primary/archive information, it is difficult to access to cutting-edge equipment, and the local idiosyncrasy might be hard to deal with. This research demonstrated that the integration of geophysical methods is a key approach for refining the hydrogeological information in the study area.

\section{Conclusions}

The geophysical methods used in both study areas demonstrated the applicability and efficiency in defining the layering and thicknesses of the different geological units. In the Punata and Toco alluvial fans a refinement of the hydrogeological models was proposed by integrating and interpreting the ERT, TDIP and TEM surveys. These refined models have more accurate information in terms of depth, lateral variation, and thicknesses of hydrogeological units. Moreover, TEM surveys assisted in delimiting a saline zone, which is important in the design and drilling of new wells. It was also important the location of a possible fault beneath the Quaternary deposits in the Punata fan due to the possibility in finding water stored in fractures, however, more studies are needed.

The results provided by this research are important for a successful hydrogeological mapping, and eventually must be used for formulating policies for groundwater management and protection. This requires that groundwater must be placed on the political agenda of the decision makers and administrative units.

Acknowledgements The present study was supported by the Swedish International Development Agency (SIDA) in collaboration with Society of Exploration Geophysicist-Geoscientists Without Borders (SEG-GWB), Lund University (Sweden), Universidad Mayor de San Simon (Bolivia). Special thanks to the Hydrogeophysics Group at Aarhus University (Denmark) who helped us. Thanks to Guideline Geo for supporting with equipment for surveys. Also thanks to all the students who collaborated during the project.

Open Access This article is distributed under the terms of the Creative Commons Attribution 4.0 International License (http://creativeco mmons.org/licenses/by/4.0/), which permits unrestricted use, distribution, and reproduction in any medium, provided you give appropriate credit to the original author(s) and the source, provide a link to the Creative Commons license, and indicate if changes were made.

\section{References}

Ahzegbobor PA (2014) Assessment of soil salinity using electrical resistivity imaging and induced polarization methods African. $\mathbf{J}$ Agric Res 9:3369-3378

Allen J (2016) Bolivia's lake Poopó disappears. NASA Earth Observatory. https://earthobservatory.nasa.gov/NaturalHazards/view. php?id=87363. Accessed 16 Mar 2017

BRGM - SEURECA (1990) Evaluación de los recursos de agua y abastecimiento de agua potable de la ciudad de Cochabamba, Bolivia (Assessment of water resources and drinking water supply in Cochabamba, Bolivia). The World Bank Program PPF444-Bo, Bolivia

Danielsen JE, Auken E, Jørgensen F, Søndergaard V, Sørensen KI (2003) The application of the transient electromagnetic method in hydrogeophysical surveys. J Appl Geophys 53:181-198

Daughney CJ, Reeves RR (2005) Definition of hydrochemical facies in the New Zealand national groundwater monitoring programme. J Hydrol N Z 44:105-130

Duran A (2018) Aguas Subterráneas: Investigación aplicada en el abanico aluvial de la cuenca del río Sichez (Groundwater: Applied research in the alluvial fan of the Sichez River watershed). Programa PIAACC. Talleres Gráficos Kipus, Cochabamba

GEOBOL (1983) Estudio geologico de la hoja de Punata cuadrangulo No 6441 (Geological study of Punata region, quadrangle No 6441). GEOBOL, La Paz

Giocoli A et al (2008) Electrical resistivity tomography investigations in the ufita Valley (southern Italy). Ann Geophys 51:213-223 
Gonzales Amaya A, Dahlin T, Barmen G, Rosberg J-E (2016) Electrical resistivity tomography and induced polarization for mapping the subsurface of alluvial fans: a case study in Punata (Bolivia). Geosciences 6:51. https://doi.org/10.3390/geosciences6040051

Gonzales Amaya A, Barmen G, Muñoz G (2018a) A multidisciplinary approach for clarifying the recharge processes and origin of saline water in the semi-arid Punata alluvial fan in Bolivia. Water 10:946

Gonzales Amaya A, Mårdh J, Dahlin T (2018b) Delimiting a saline water zone in quaternary fluvial-alluvial deposits using transient electromagnetic: a case study in Punata, Bolivia. Environ Earth Sci 77:46. https://doi.org/10.1007/s12665-017-7213-5

Grey D, Garrick D, Blackmore D, Kelman J, Muller M, Sadoff C (2013) Water security in one blue planet: twenty-first century policy challenges for science. Philos Trans R Soc A 371:20120406

Guérin R, Descloitres M, Coudrain A, Talbi A, Gallaire R (2001) Geophysical surveys for identifying saline groundwater in the semi-arid region of the central Altiplano, Bolivia. Hydrol Process 15:3287-3301. https://doi.org/10.1002/hyp.284

Habermehl M (2006) The great artesian basin, Australia. UNESCO Groundwater 10:82-88

INE (2012) Censo Poblacion y Vivienda 2012 (Population and Housing Census 2012). Instituto Nacion de Estadistica. Estado Plurinacional de Bolivia. http://www.ine.gob.bo/. Accessed 5 July 2017

Keys WS (2017) A practical guide to borehole geophysics in environmental investigations, 1st edn. Routledge, New York, pp 6-8

Klee P (2013) Greater water security with groundwater. Groundwater mapping and sustainable groundwater management. The Rethink Water network and Danish Water Forum, Copenhagen

Koch K, Revil A, Holliger K (2012) Relating the permeability of quartz sands to their grain size and spectral induced polarization characteristics. Geophys J Int 190:230-242

Lobina E (2000) Cochabamba: water war. Focus PSI Journal) 7:6

Loke M (2010) Res2DInv ver 3.59. 102. Geoelectrical imaging 2D and 3D. Instruction manual. Geotomo Software. Minden Heights, Malaysia

Loke M, Dahlin T (2002) A comparison of the Gauss-Newton and quasi-Newton methods in resistivity imaging inversion. J Appl Geophys 49:149-162

Loke MH, Acworth I, Dahlin T (2003) A comparison of smooth and blocky inversion methods in 2D electrical imaging surveys. Explor Geophys 34:182-187

Magnusson M, Fernlund JR, Dahlin T (2010) Geoelectrical imaging in the interpretation of geological conditions affecting quarry operations. Bull Eng Geol Environ 69:465-486. https://doi.org/10.1007/ s10064-010-0286-y

May J-H, Zech J, Zech R, Preusser F, Argollo J, Kubik PW, Veit H (2011) Reconstruction of a complex late Quaternary glacial landscape in the Cordillera de Cochabamba (Bolivia) based on a morphostratigraphic and multiple dating approach. Quat Res 76:106-118. https://doi.org/10.1016/j.yqres.2011.05.003

Olsson P-I, Dahlin T, Fiandaca G, Auken E (2015) Measuring timedomain spectral induced polarization in the on-time: decreasing acquisition time and increasing signal-to-noise ratio. J Appl Geophys 123:316-321
Power C, Tsourlos P, Ramasamy M, Nivorlis A, Mkandawire M (2018) Combined DC resistivity and induced polarization (DC-IP) for mapping the internal composition of a mine waste rock pile in Nova Scotia. Can J Appl Geophys 150:40-51

Revil A, Florsch N (2010) Determination of permeability from spectral induced polarization in granular media. Geophys J Int 181:1480-1498

Revil A, Binley A, Mejus L, Kessouri P (2015) Predicting permeability from the characteristic relaxation time and intrinsic formation factor of complex conductivity spectra. Water Resour Res 51:6672-6700

Saldías C, Boelens R, Wegerich K, Speelman S (2012) Losing the watershed focus: a look at complex community-managed irrigation systems in Bolivia. Water Int 37:744-759. https://doi. org/10.1080/02508060.2012.733675

Saldías C, Speelman S, Van Huylenbroeck G (2013) Access to irrigation water and distribution of water rights in the Abanico Punata, Bolivia. Soc Nat Resour 26:1008-1021. https://doi. org/10.1080/08941920.2012.729651

Satgé F et al (2017) Role of climate variability and human activity on Poopó lake droughts between 1990 and 2015 assessed using remote sensing data. Rem Sens 9:218

Slater L (2007) Near surface electrical characterization of hydraulic conductivity: from petrophysical properties to aquifer geometries-a review. Surv Geophys 28:169-197. https://doi. org/10.1007/s10712-007-9022-y

Slater LD, Lesmes D (2002) IP interpretation in environmental investigations. Geophysics 67:77-88

Sørensen KI, Auken E (2004) SkyTEM-a new high-resolution helicopter transient electromagnetic system. Explor Geophys $35: 194-202$

Sumner JS (2012) Principles of induced polarization for geophysical exploration, vol 5. Elsevier, Amsterdam

Thomsen R, Søndergaard V, Sørensen K (2004) Hydrogeological mapping as a basis for establishing site-specific groundwater protection zones in Denmark. Hydrogeol J 12:550-562

UNDP-GEOBOL (1978) Proyecto Integrado de Recursos Hidricos Cochabamba (Integrated Water Resources Project Cochabamba), vol 1. United Nations Development Programme, Cochabamba

UNESCO (2015) Regional strategy for the evaluation and management of transboundary aquifer systems in the Americas. In: American Geophysical Union, H51A-1350

UN-Water (2013) Water security and the global water agenda. Institute for Water, Environment and Health (UNU-INWEH), Ontario

Weller A, Slater L, Nordsiek S (2013) On the relationship between induced polarization and surface conductivity: Implications for petrophysical interpretation of electrical measurements. Geophysics 78:D315-D325

Wutich A, Ragsdale K (2008) Water insecurity and emotional distress: coping with supply, access, and seasonal variability of water in a Bolivian squatter settlement. Soc Sci Med 67:2116-2125

Yihdego Y, Nzikou MM (2018) Application of airborne geophysics and geochemistry to characterize groundwater flow path. Geotech Geol Eng 36:1175-1184 